\title{
PEMANFAATAN SARANA PRASARANA KERJA, SELF CAPACITY BUILDING , DAN KINERJA TENAGA ADMINISTRASI SEKOLAH
}

Oleh :

Winda Achmadwati , Danny Meirawan, Yayah Rahyasih

Sekolah Pascasarjana Universitas Pendidikan Indonesia

(email: winda0204@student.upi.edu*, dmeirawan@upi.edu, rahyasih@upi.edu)

\begin{abstract}
ABSTRAK
Penelitian ini bertujuan mengkaji pemanfaatan sarana prasarana kerja dan self capacity building terhadap kinerja tenaga administrasi sekolah. Penelitian ini menggunakan metode deskriptif dengan pendekatan kuantitatif yang dilakukan terhadap 109 tenaga administrasi sekolah. Dari hasil penelitian yang dilakukan, pemanfaatan sarana prasarana berpengaruh signifikan terhadap kinerja tenaga administrasi sekolah pada kategori sangat tinggi. Hal ini dapat dijelaskan dari tingginya hubungan kedua dimensi pemanfaatan sarana prasarana kerja terhadap kinerja yang diukur yaitu berdasarkan prinsip dan fungsi sarana prasarana kerja. Self capacity building juga berpengaruh signifikan terhadap kinerja tenaga administrasi sekolah meskipun berpengaruh pada kategori sedang. Hal ini teridentifikasi dari rendahnya hubungan lima indikator self capacity building terhadap kinerja tenaga administrasi sekolah yang diukur, yaitu workshop, seminar, courses, co-operative collegial development, dan skill development model. Pemerintah hendaknya lebih memperhatikan ketersediaan, kelayakan dan kenyamanan sarana prasarana kerja serta mengadakan berbagai pelatihan yang ditujukan untuk tenaga administrasi sekolah dalam upaya meningkatkan capacity building tenaga administrasi sekolah dapat bekerja.
\end{abstract}

Kata Kunci : Kinerja Tenaga Administrasi Sekolah, Pemanfaatan Sarana Prasarana Kerja, Self Capacity Building

ABSRACT

This research aims to examine the utilization of work infrastructure and self capacity building on the performance of school administrative staff. This research uses descriptive method with quantitative approach done to 109 school administration personnel. From the results of research conducted, the utilization of infrastructure facilities have a significant effect on the performance of school administrative staff on very high category. This can be explained by the high relation between the two dimensions of utilization of work infrastructure to the measured performance that is based on the principle and function of work infrastructure. Self capacity building also has a significant effect on the performance of school administrative personnel although it affects the middle category. This is identified by the low relation of five indicators of self capacity building to the performance of school administrative staff, ie workshop, seminar, courses, cooperative collegial development, and skill development model. The government should pay more attention to the availability, feasibility and convenience of work infrastructure and conduct various training aimed at the school administrative staff in an effort to increase the capacity building of school administration personnel to work.

Keywords : Infrastructure Utilization, Performance of administrative personnel schools, Self Capacity Building

\section{PENDAHULUAN}

Pemenuhan standar kualifikasi dan standar kompentensi bagi tenaga administrasi di jenjang pendidikan dasar dan menengah dalam jabatan merupakan hak yang wajib dipenuhi oleh penyelenggara sekolah. Keberadaan tenaga administrasi sekolah di jenjang pendidikan dasar dan menengah dalam proses pembelajaran sangat diperlukan. Sebagai suatu komponen dalam proses pembelajaran, tugas dan fungsi tenaga administrasi sekolah dijenjang pendidikan dasar dan menengah tidak dapat digantikan oleh pendidik. Hal ini disebabkan: pekerjaannya bersifat administratif yang tunduk pada aturan yang sifatnya khusus, merupakan pekerjaan pelayanan untuk kelancaran proses pembelajaran, lebih memerlukan keterampilan khusus, memerlukan keahlian tertentu, memerlukan kompetensi yang berbeda dengan kompetensi yang disyaratkan untuk pendidik.

Di Inggris, untuk urusan administrasi mereka dibagi menjadi 4 bagian, yaitu; school assistant (Asisten sekolah), administration assistant (asisten administrasi), finance assistant (asisten keuangan) dan general assistant (asisten umum) (Hazel Callaghan (2011, hlm. 11),. Staf tata usaha masuk bekerja di sekolah didasarkan pada profesionalisme mereka. Sebelum bekerja disekolah mereka harus mendapatkan skill dan pengetahuan yang cukup untuk kerja mereka. Oleh karena itu pengalaman dan sertifikat pendidikan (ijazah) sangat menentukan dalam kerja mereka 
dan mereka bekerja pada disiplin ilmu mereka masing-masing.

Hal ini berbeda dengan staf TU yang ada di Indonesia, semua staf TU di sekolah-sekolah di Indonesia tampaknya harus bisa bekerja di semua bidang yang ditugaskan oleh kepala sekolah dan kepala TU. Mereka bertugas dalam berbagai bidang, baik bekerja sama dengan kepala sekolah dan guru atau mereka bekerja sendiri. Dari segi lulusan pendidikan, untuk bekerja menjadi tenaga administrasi sekolah di Indonesia tidak ada patokan jenjang pendidikan tertentu, ini terbukti dari hasil studi pendahuluan yang dilakukan oleh peneliti bahwa rata-rata tenaga administrasi sekolah berpendidikan hanya lulusan SMA (sekitar 51\%) dan hanya sedikit yang berpendidikan S1 (30\%) selebihnya berpendidikan SMP bahkan SD. (Sumber: Dinas Pendidikan Kota Bandung).

Berdasarkan hasil studi pendahuluan (Agustus-Desember, 2016) yang dilakukan peneliti, yaitu pengamatan di beberapa Sekolah Menengah Pertama Negeri di Kota Bandung, bahwa ada beberapa indikator yang menunjukkan bahwa kinerja pegawai tata usaha sekolah masih rendah, yaitu : Pertama, masih banyak pegawai tata usaha sekolah yang belum mempunyai kemampuan, kecakapan atau keahlian yang memadai untuk mengerjakan tugas-tugas mereka dengan performa yang baik dan memuaskan. Contoh paling sederhana ialah masih sangat banyaknya tenaga adiministrasi sekolah yang belum bisa mengoperasikan komputer dengan baik untuk urusan administrasi sekolah. Selain masih minimnya perhatian pemerintah dalam mengembangkan kinerja tenaga administrasi sekolah melalui pelatihan, alasan yang paling mendasar adalah karena keterbatas usia, hal ini didukung oleh peroleh data dari Dinas Pendidikan Kota Bandung, bahwa sekitar 69\% tenaga administrasi sekolah adalah sudah berusia 50 tahun ke atas. Di sisi lain, ada tuntutan seluruh administrasi sekolah saat ini menggunakan komputer dan menggunakan sistem online yang secara langsung menuntut para tenaga administrasi harus cakap dalam menggunakan fasilitas teknologi yang semakin modern. Hal tersebut didukung oleh pengakuan para pegawai di Dinas Pendidikan Kota Bandung di Bidang Sekolah Dasar dan Menengah yang mengaku seringnya terjadi keterlambatan pengumpulan data atau pengisian data yang dilakukan oleh para tenaga administrasi, fenomena tersebut sudah menjadi hal biasa bagi para pegawai Dinas, keterlambatan tersebut dapat berlangsung sekitar semingggu sampai dua minggu dari jadwal deadline yang sudah ditetapkan. Kedua, masih rendahnya disiplin, loyalitas dan tanggung jawab tenaga administrasi sekolah dalam menjalankan tugastugas mereka sebagai tenaga administrasi sekolah. Ketaatan sebagian mereka barulah sekedar ketika ada kepala sekolah. Ketiga, masih belum tercerminnya pelayanan prima yang diberikan kepada siswa, orang tua, dan masyarakat. Banyak orang tua, siswa ataupun warga masyarakat yang berurusan kurang dilayani dengan penuh keramahan, penuh perhatian, cepat, tepat, mudah dan tidak berbelit-belit. Terkadang kala ternyata untuk mengurus surat pindah maupun surat keterangan saja harus batele-tele. Keempat, masih kurang tersedianya sarana prasarana untuk menunjang dalam bekerja. Hal tersebut salah satunya terindikasi dari masih sedikitnya sekolah yang memasang wifi/jaringan internet, kemudian ketersediaan perangkat komputer pun masih terbatas, serta dari segi tata ruang dan luas ruang tenaga administrasi pun tidak sedikit sekolah menengah pertama di kota Bandung yang memiliki luas dan tata ruang serta pencahayaan yang kurang baik, kondisi tersebut dijumpai di beberapa sekolah bercluster III. Selain itu, di bidang-bidang lain juga terlihat masih banyak kesemerutan kerja tata usaha sekolah seperti pengarsipan surat yang tidak tertata rapi, surat masuk dan keluar sering hilang, datadata sekolah banyak yang tidak lengkap dan tidak ada, dan kalaupun ada banyak yang tidak up to date (Studi Pendahuluan, Desember 2016).

Penelitian terkait kinerja tenaga administratif telah dilakukan oleh Sartini (2010) menjelaskan bahwa kinerja tenaga administratif sekolah atau staff tata usaha sangat dipengaruhi oleh leadership kepala sekolah baik dalam hal menciptakan hubungan yang positif, pemberian umpan balik dan menciptakan budaya sekolah yang harmonis serta menciptakan suasa komunikasi yang kondusif. Selanjutnya, penelitian yang dilakukan oleh Tartini dan Zulkifli (2016) menjelaskan bahwa tenaga administrasi sekolah/madrasah masih belum mendapatkan pelatihan khusus tentang kompetensi manajerial, dan rangkap jabatan yang membuat sebagian kepala tenaga administrasi kurang maksimal dalam menjalan kompetensi manajeril. Afriyenti (2013) menjelaskan bahwa setiap tenaga administratif perlu diberdayakan secara efektif dan efesien untuk meningkatkan layanan yang diberikan.

Kinerja adalah kemampuan (Ability) dan motivasi (Motivation). Hal tersebut sesuai dengan pendapat John W. Atkinson (dalam Wibowo, 2007, hlm. 99) mengemukakan bahwa : "kinerja merupakan fungsi motivasi dan kemampuan. Dengan demikian, model persamaan kinerja $=\mathrm{f}$ (motivasi, kemampuan)." 
Dalam berbagai referensi dapat diketahui berbagai faktor yang mempengaruhi kinerja menurut Armstrong dan Baron (dalam Wibowo, 2007, hlm. 99) yaitu : "personal factor, leadership, team factor, system factor." Selain itu menurut Sutermeister (1976, hlm. 11) memaparkan bahwa: Kinerja atau performance dipengaruhi oleh 2 unsur yaitu motivation dan ability. Unsur-unsur yang ada dari motivasi yaitu phsycal conditions, individuals phsycological social egoistic, formal organization, informal organization (groups). Unsur dari ability yaitu skill dan knowledge.

Dari pengertian kinerja diatas, jadi kinerja merupakan kemampuan yang dimiliki berdasarkan pada tugas dan tanggung jawab dan didorong oleh motivasi dalam manghasilkan suatu pekerjaan. Dimensi dari kinerja tenaga administrasi sekolah dalam penelitian ini yaitu dilihat dari loyalitas, semangat kerja, prakarsa, tanggung jawab, dan pencapaian target.

Faktor pertama yang mempengaruhi kinerja dari unsur motivation (motivasi) yaitu dilihat dari phsycal conditions atau kondisi fisik organisasi, yaitu pemanfaatan saran pra sarana, Menurut Suharsimi Arikunto dalam Arum (2007, hlm. 6) menyatakan bahwa sarana pendidikan adalah semua fasilitas yang diperlukan dalam proses belajar mengajar agar pencapaian tujuan pendidikan dapat berjalan dengan lancar, teratur, efektif dan efisien, sedangkan pra sarana pendidikan adalat alat yang tidak langsung yang digunakan untuk mencapai tujuan pendidikan, misalnya: bangunan sekolah, lapangan olahraga, asrama murid dan lain-lain.

Menurut Arum (2007, hlm. 34) terdapat sembilan komponen dalam pemanfaatan sarana prasarana, yaitu pemanfaatan berdasarkan jenis, prinsip, fungsi, perencanaan, pengadaan, penggunaan, pemeliharaan, inventarisasi, dan penghapusan sarana prasarana.

Dari definisi di atas dapat diambil kesimpulan bahwa konsep pemanfaatan sarana prasaran merupakan semua komponen yang secara langsung maupun tidak langsung yang dapat menunjang jalannya proses pendidikan untuk mencapai tujuan dalam pendidikan itu sendiri. Dimensi pemanfaatan sarana prasarana dalam penelitian ini yaitu dilihat dari prinsip dan fungsi pemanfaatan sarana prasarana.

Faktor kedua yang mempengaruhi kinerja dari unsur ability (kemampuan) adalah Self Capacity Building. Pada prosesnya, capacity building merupakan sebuah pengembangan yang akan menuntut kegiatan sebuah organisasi mencapai tujuannya, hal tersebut seperti yang dijelaskan Matachi (2006, hlm. 4) yang mengatakan bahwa : "Capacity building is a process by wich individuals, groups, institutions, organizations and societies enhance their abilities to identify and meet development challenges in a sustainable manner".

Maksud dari pernyataan tersebut merupakan pengertian dari pengembangan kapasitas yang dapat diartikan sebagai proses untuk meningkatkan kemampuan individu, organisasi, dan sebuah institusi untuk meningkatkan kemampuan dalam menghadapi tantangan yang berkelanjutan.

Kolegalitas dalam sebuah organisasi akan sangat mempengaruhi individu dalam melakukan pekerjaannya. Dalam self capacity builing secara tidak langsung mempersiapkan interaksi antar individu, hal tersebut seperti dipaparkan oleh Matachi (2006, hlm. 4) yang mengemukakan bahwa : Any self capacity building activity, including training workshop and country projects, should make an effort to build capacity of stakeholders from different groups of socienty, and provide a platfrom for these groups to interact with each other. Selanjutnya menurut Matachi (2006, hlm. 4) kunci self capacity building terdapat pada tiga level, yaitu self/individual, organization, dan environment.

Dari definisi di atas dapat diambil kesimpulan bahwa makna self capacity building dapat diartikan sebagai pengembangan bakat atau kemampuan seseorang, yang mempunyai keterkaitan dengan pemerintah, organisasi, lembaga dan individu pada tingkatan tertentu yang berfungsi untuk mengembangkan kemampuan dalam mencapai tujuan. Self capacity building tidak hanya sebatas meningkatkan kemampuan dan pengetahuan akan tetapi untuk memperkuat hubungan, nilai, sikap dan lain sebagainnya. Dimensi dari self capacity building dalam penelitian ini yaitu dilihat dari workshop/sminar/courses, co-operative vollegial development, dan skill development model.

Seiring perkembangan ilmu pengetahuan dan teknologi yang terus berkembang pesat, secara langsung disadari maupun tidak disadari berdampak pada perkembangan organisasi demikian juga sekolah. Persyaratan kemampuan yang diperlukan orang untuk melakukan berbagai macam pekerjaan semakin meningkat. Profesional menjadi tuntutan dari setiap pekerjaan, dengan demikian kebutuhan sumber daya manusia yang profesional merupakan suatu keharusan dalam menjawab tantangan terhadap pelaksanaan tugas pokok dan fungsi saat ini dan di masa depan yang semakin kompleks. 
Sehubungan dengan upaya pemerintah untuk mewujudkan Good Governance mutlak diperlukan aparatur yang bersih dan berwibawa, memiliki dedikasi, kreatifitas, inovatif, kredibilitas serta akuntabilitas. Untuk menwujudkan harapan tersebut, maka perlu didukung dengan kesempatan untuk menggunakan sarana, prasarana, dan fasilitas pendidikan untuk menunjang kelancaran pelaksanaan tugas dan pembinaan karier sesuai dengan tuntutan pengembangan kualitas sebagaimana disebutkan dalam UU No. 20 Tahun 2003, sehingga mampu menunjukkan kinerja yang lebih baik. Mencermati fenomena tersebut penulis tertarik untuk melakukan penelitian, dan melalui penelitian ini diharapkan dapat melihat secara jelas, aktual dan faktual mengenai pemanfaatan sarana prasaran dan self capacity building dalam mendukung peningkatan kinerja tenaga administrasi sekolah

\section{METODE PENELITIAN}

Penelitian ini membahas tentang pengaruh pemanfaatan sarana prasarana dan self capacity building terhadap kinerja tenaga administrasi sekolah. Penelitian ini diarahkan untuk mengetahui gambaran empirik tentang pemanfaatan sarana prasarana dan self capacity building pada Sekolah Menengah Pertama Negeri se- Kota Bandung yang mana hasilnya diharapkan akan bermanfaat bagi peningkatan kinerja tenaga administrasi sekolah di waktu mendatang.

Lokasi penelitian teridiri dari Sekolah Menengah Pertama Negeri se- Kota Bandung. Penelitian ini terdiri dari tiga variabel yaitu variabel pemanfaatan sarana prasarana, variabel self capacity building dan variabel kinerja tenaga administrasi sekolah. Untuk menggali informasi mengenai bagaimana variabel tersebut, maka data penelitian ini merupakan nilai persepsi tenaga administrasi sekolah, oleh sebab itu yang dijadikan anggota populasi penelitian ini adalah tenaga administrasi sekolah yang sudah diangkat menjadi Pegawai Negeri Sipil di lingkungan Sekeolah Menengah Pertama Negeri se-Kota Bandung.

Populasi penelitian ini adalah tenaga administrasi sekolah yang sudah diangkat menjadi Pegawai Negeri Sipil berjumlah 272 orang di Sekolah Menengah Pertama Negeri yang ada di Kota Bandung sebanyak 54 sekolah yang terbagi ke dalam enam wilayah sesuai kecamatan, yaitu 11 sekolah berada pada wilayah A, 12 sekolah berada pada wilayah B, 5 sekolah berada pada wilayah C,
6 sekolah berada pada wilayah D, 4 sekolah berada pada wilayah E, 6 sekolah berada pada wilayah $\mathrm{F}$, dan 10 sekolah berada pada wilayah G.

Sesuai dengan karakteristik subjek penelitian (masing-masing sekolah) yang tersebar di berbagai daerah di Kota Bandung dan diklasifikasikan menurut rayon, maka penarikan sampel dilakukan dengan teknik tahapan atau multi stage sampels (Sudjana, 2009, hlm. 73).

Dengan demikian, sampel dalam penelitian ini adalah tenaga administrasi sekolah dari ke 30 Sekolah Menengah Pertama Negeri di Kota Bandung sebanyak 109 orang. Hal ini dilakukan dengan pertimbangan jika subyeknya besar maka dapat diambil antara $10 \%-15 \%$ atau 20\% - 25\% atau lebih (Arikunto, 2006, hlm. 63).

Penetapan jumlah sampel ini sejalan dengan teknik penetapan sampel menggunakan rumus dari Taro Yamane (dalam Sugiyono, 2009, hlm. 30), yaitu :

$$
\begin{array}{ll} 
& n=\mathrm{N} . \mathrm{d}+1 \\
\mathrm{n} & \text { : Banyaknya sampel } \\
\mathrm{N} & \text { : Jumlah populasi } \\
\mathrm{d} & \text { : Presisi yang diterapkan }
\end{array}
$$

Dengan menggunakan formula tersebut, diketahui jumlah responden tenaga administrasi sekolah dalam penelitian ini sebanyak (N) 272 orang. Tingkat presisi yang diterapkan sebesar 40\%, maka diperoleh :

$\mathrm{n}=272.0,40+1$

$\mathrm{n}=108+1$

$\mathrm{n}=109$

\section{HASIL PENELITIAN}

\section{Deskripsi Kinerja Tenaga Administrasi Sekolah}

Dari hasil penelitian diperoleh informasi bahwa Kinerja Tenaga Administrasi Sekolah di Sekolah Menengah Pertama Negeri Se Kota Bandung teridentifikasi pada kategori sangat tinggi. Hal ini didasarkan dari hasil perhitungan WMS yang ditunjukkan sebesar 4,07 dan jika dikonsultasikan berada pada kategori sangat tinggi. Kinerja Tenaga Administrasi Sekolah terbagi menjadi 5 dimensi, yaitu Pertama, loyalitas. Kedua, semangat kerja. Ketiga, prakarsa. Keempat, tanggung jawab. Kelima, pencapaian target.

\section{Deskripsi Pemanfaatan Sarana Prasarana Kerja}

Dari hasil penelitian diperoleh informasi bahwa Pemanfaatan Sarana Prasarana Kerja oleh para pegawai tenaga administrasi sekolah di 
Sekolah Menengah Pertama Negeri Kota Bandung teridentifikasi pada kategori sangat tinggi. Hal ini didasarkan dari hasil perhitungan WMS yang ditunjukkan sebesar 4,27 dan jika dikonsultasikan berada pada kategori sangat tinggi. Pemanfaatan Sarana Prasarana Kerja dalam penelitian ini terbagi menjadi 2 dimensi, yaitu Pertama, Prinsip Pemanfaatan Sarana Prasarana Kerja. Kedua, Fungsi Sarana Prasarana Kerja.

\section{Deskripsi Self Capacity Building}

Dari hasil penelitian diperoleh informasi bahwa Self Capacity Building Tenaga Administrasi Sekolah di Sekolah Menengah Pertama Negeri Kota Bandung teridentifikasi pada kategori tinggi. Hal ini didasarkan dari hasil perhitungan WMS yang ditunjukkan sebesar 3,92 dan jika dikonsultasikan berada pada kategori tinggi. Dalam Penelitian ini Variabel Self Capacity Building terbagi menjadi 2 dimensi, yaitu Pertama, dinilai dari faktor Eksternal. Kedua, dinilai dari faktor Internal.

\section{Pengujian Hipotesis \\ Pengaruh Pemanfaatan Sarana Prasarana Kerja terhadap Kinerja Tenaga Administrasi Sekolah}

Hipotesis dalam penelitian ini adalah “ terdapat pengaruh yang signifikan dari Pemanfaatan Sarana Prasarana Kerja terhadap Kinerja Tenaga Administrasi Sekolah. Hasil perhitungan dengan bantuan SPSS 23 for Windows nilai korelasi variabel Pemanfaatan Sarana Prasarana Kerja (X1) terhadap Kinerja Tenaga Administrasi Sekolah (Y) menggunakan Korelasi Pearson Product Moment, nilai korelasi yang diperoleh untuk X1 dengan Y sebesar 0,820 berarti terdapat hubungan antara Pemanfaatan Sarana Prasarana Kerja terhadap Kinerja Tenaga Administrasi Sekolah. Uji signifikasi untuk X1 dengan $\mathrm{Y}$ yang ditunjukkan tabel diperoleh nilai signifikan 0,000 yakni lebih kecil dari nilai probabilitas 0.05 , yang artinya terdapat hubungan yang signifikan. Maka kesimpulan yang dapat diambil adalah terdapat hubungan signifikan antara Pemanfaatan Sarana Prasarana Kerja terhadap Kinerja Tenaga Administrasi Sekolah pada tingkat sangat kuat. Hasil perhitungan nilai koefisien determinasi variabel Pemanfaatan Sarana Prasarana terhadap Kinerja Tenaga Administrasi Sekolah dapat diketahui besarnya koefisien determinasi variabel Pemanfaatan Sarana Prasarana Kerja (X1) terhadap Kinerja Tenaga Administrasi Sekolah (Y) adalah sebesar 0,673 atau 67,3 \%. Artinya Kinerja Tenaga Administrasi Sekolah dipengaruhi oleh variabel Pemanfaatan Sarana Prasarana Kerja sebesar $67,3 \%$ sedangkan selebihnya dipengaruhi oleh faktor lain. Rumus persamaan regresi antara variabel Pemanfaatan Sarana Prasarana Kerja dengan Kinerja Tenaga Administrasi Sekolah adalah $\hat{Y}=a+b X_{l}$. perhitungan dengan bantuan SPSS 23 for Windows diperoleh hasil persamaan regresi $\mathrm{Y}$ atas $\mathrm{X}_{1}$, adalah $\hat{Y}=9,500+0,873 X_{1}$. Dengan persamaan regresi tersebut dapat diinterprestasikan bahwa jika variabel Pemanfaatan Sarana Prasarana Kerja $\left(\mathrm{X}_{1}\right)$ dengan Kinerja Tenaga Administrasi Sekolah (Y) diukur dengan instrumen yang dikembangkan dalam penelitian ini, maka setiap perubahan skor Pemanfaatan Sarana Prasarana Kerja sebesar satu satuan dapat diestimasikan skor Kinerja Tenaga Administrasi Sekolah akan berubah sebesar 0,873 satuan pada arah yang sama.

\section{Pengaruh Self Capacity Building terhadap \\ Kinerja Tenaga Administrasi Sekolah}

Hipotesis dalam penelitian ini adalah “ terdapat pengaruh yang signifikan dari Self Capcity Building terhadap Kinerja Tenaga Administrasi Sekolah. Hasil perhitungan dengan bantuan SPSS 23 for Windows nilai korelasi variabel Self Capacity Building (X2) terhadap Kinerja Tenaga Administrasi Sekolah (Y) menggunakan Pearson Product Moment adalah nilai korelasi yang diperoleh untuk $\mathrm{X}_{2}$ dengan $\mathrm{Y}$ sebesar 0,405 berarti terdapat hubungan antara Self Capacity Building terhadap Kinerja Tenaga Administrasi Sekolah. Uji signifikasi untuk $\mathrm{X}_{2}$ dengan $\mathrm{Y}$ yang ditunjukkan tabel diperoleh nilai signifikan 0,000 yakni lebih kecil dari nilai probabilitas 0.05 , yang artinya terdapat hubungan yang signifikan. Maka kesimpulan yang dapat diambil adalah terdapat hubungan signifikan antara Self Capacity Building terhadap Kinerja Tenaga Administrasi Sekolah pada tingkat sedang. Hasil perhitungan nilai koefisien determinasi variabel Self Capacity Building $\left(\mathrm{X}_{2}\right)$ terhadap Kinerja Tenaga Administrasi Sekolah (Y) dapat diketahui besarnya koefisien determinasi variabel Self Capacity Building $\left(\mathrm{X}_{2}\right)$ terhadap Kinerja Tenaga Administrasi Sekolah (Y) adalah sebesar 0,164 atau 16,4\%. Artinya Kinerja Tenaga Administrasi Sekolah dipengaruhi oleh variabel Self Capacity Building sebesar 16,4\% sedangkan selebihnya dipengaruhi oleh faktor lain. Rumus persamaan regresi antara variabel Self Capacity Building dengan Kinerja Tenaga Administrasi Sekolah adalah $\hat{Y}=a+b X_{1}$. perhitungan dengan bantuan SPSS 23 for Windows diperoleh hasil persamaan regresi $\mathrm{Y}$ atas $\mathrm{X}_{2}$, adalah $\hat{\mathrm{Y}}=63,357+$ $0,667 X_{2}$. Dengan persamaan regresi tersebut dapat 
diinterprestasikan bahwa jika variabel Self Capacity Building $\left(\mathrm{X}_{2}\right)$ dengan Kinerja Tenaga Administrasi Sekolah (Y) diukur dengan instrumen yang dikembangkan dalam penelitian ini, maka setiap perubahan skor Self Capacity Building sebesar satu satuan dapat diestimasikan skor Kinerja Tenaga Administrasi Sekolah akan berubah sebesar 0,667 satuan pada arah yang sama.

\section{Pengaruh Pemanfaatan Sarana Prasarana Kerja (X1) dan Self Capacity Building (X2) terhadap Kinerja Tenaga Administrasi Sekolah (Y) di SMP Negeri Se Kota Bandung} Hipotesis dalam penelitian ini adalah “ terdapat pengaruh yang signifikan dari Pemanfaatan Sarana Prasarana Kerja dan Self Capacity Building terhadap Kinerja Tenaga Administrasi Sekolah.

Analisis koefisien ganda dimaksudkan untuk mengetahui derajat keterkaitan atau hubungan antara Pemanfaatan Sarana Prasarana Kerja dan Self Capacity Building terhadap Kinerja Tenaga Administrasi Sekolah. Untuk uji korelasi ini menggunakan rumus korelasi ganda. Hasil perhitungan dengan bantuan SPSS 23 for Windows nilai korelasi diketahui hasil korelasi ( $\mathrm{R}$ ) sebesar 0,834 yang berarti bahwa terdapat korelasi ganda yang positif dari Pemanfaatan Sarana Prasarana Kerja dan Self Capacity Building terhadap Kinerja Tenaga Administrasi Sekolah. Berdasarkan kriteria harga koefisien korelasi $\mathrm{r}$ hitung 0,834 menunjukkan tingkat hubungan sangat kuat. Dengan demikian dapat disimpulkan bahwa terdapat korelasi ganda positif yang sedang antara Pemanfaatan Sarana Prasarana Kerja dan Self Capacity Building terhadap Kinerja Tenaga Administrasi Sekolah di SMP Negeri Se Kota Bandung. Dari hasil pengolahan data diatas diperoleh nilai signifikansi 0,000 . Karena nilai probabilitas jauh lebih kecil dari 0,05 maka model regresi dapat dipakai untuk memprediksi variabel Y. Maka dapat disimpulkan bahwa Variabel Pemanfaatan Sarana Prasarana Kerja dan Variabel Self Capacity Building secara bersama-sama memiliki signifikansi positif terhadap Variabel Kinerja Tenaga Administrasi Sekolah di SMP Negeri Se Kota Bandung. Hasil perhitungan nilai koefisien determinasi variabel Pemanfaatan Sarana Prasarana Kerja $\left(\mathrm{X}_{1}\right)$ dan variabel Self Capacity Building (X2) terhadap Kinerja Tenaga Administrasi Sekolah (Y) dapat diketahui besarnya koefisien determinasi variabel Pemanfaatan Sarana Prasarana Kerja dan variabel Self Capacity Building terhadap Kinerja Tenaga Administrasi Sekolah di SMP Negeri Se Kota Bandung adalah sebesar 0,695 atau 69,5\%. Artinya Kinerja Tenaga Administrasi Sekolah dipengaruhi oleh variabel Pemanfaatan Sarana Prasarana Kerja dan Self Capacity Building sebesar 69,5\% sedangkan selebihnya dipengaruhi oleh faktor lain. Rumus persamaan regresi antara variabel Pemanfaatan Sarana Prasarana Kerja dan Self Capacity Building terhadap Kinerja Tenaga Administrasi Sekolah adalah $\hat{Y}=a+b X_{1}+\mathrm{b} X_{2}$. perhitungan dengan bantuan SPSS 23 for Windows diperoleh hasil dengan persamaan $\mathrm{Y}=0,319+$ $0,820 \mathrm{X}_{1}+0,258 \mathrm{X}_{2}$, konstanta sebesar 0,319 menyatakan bahwa jika tidak ada faktor Pemanfaatan Sarana Prasarana Kerja $\left(\mathrm{X}_{1}\right)$, Self Capacity Building $\left(\mathrm{X}_{2}\right)$ maka Kinerja Tenaga Administrasi Sekolah (Y) adalah 0,319. Koefisien regresi $X_{1}$ sebesar 0,820 menyatakan bahwa setiap penambahan satu unit Pemanfaatan Sarana Prasarana Kerja maka Kinerja Tenaga Administrasi Sekolah akan meningkat sebesar 0,820, sementara Self Capacity Building $\left(\mathrm{X}_{2}\right)$ konstan. Koefisien regresi $X_{2}$ sebesar 0,258 menyatakan bahwa setiap penambahan satu unit Self Capacity Building $\left(\mathrm{X}_{2}\right)$ maka Kinerja Tenaga Administrasi Sekolah (Y) akan meningkat sebesar 0,258 sementara Pemanfaatan Sarana Prasarana Kerja konstan.

Dari pemparan tersebut digambarkan struktur Pemanfaatan Sarana Prasarana Kerja dan Self Capacity Building terhadap Kinerja Tenaga Administrasi Sekolah di Sekolah Mennegah Pertama Negeri Se Kota Bandung.

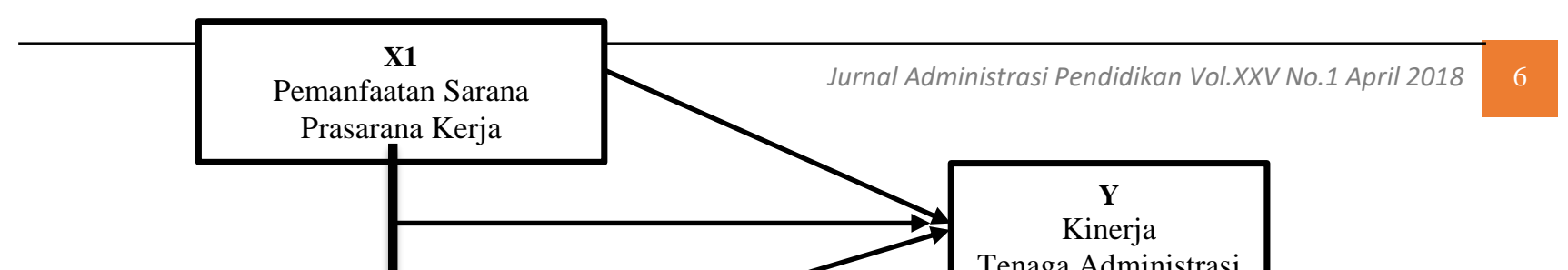




\section{Pembahasan Kinerja Tenaga Administrasi Sekolah}

Penyelenggaraan dan keberhasilan proses pendidikan pada semua jenjang dan satuan pendidikan tidak akan terlepas dari peran tenaga administrasi sekolah. Oleh karena itu, jika kualitas dan kinerja tenaga administrasi sekolah yang rendah akan berdampak pada kelancaran penyelenggaraan pendidikan. Melihat peran tenaga administrasi sekolah dalam penyelenggaraan pendidikan tersebut, maka tenaga administrasi sekolah perlu meningkatkan kompetensinya secara terus menerus, terutama kompetensi yang terkait dengan tugas atau pekerjaan administratif, sehingga dengan kemampuannya itu tenaga administrasi sekolah dapat meningkatkan kinerjanya. Hal tersebut sejalan dengan penelitian yang dilakukan oleh James P. Spillane dan Allison W. Kenney (2012, hal. 541) penelitian tersebut mengatakan betapa pentingnya peran dari administrasi sekolah sebagai keberhasilan pelaksana keberhasilan kebijakan dan program pemerintah. Meskipun demikian, untuk dapat menjalankan perannya secara optimal, tenaga administrasi sekolah tetap membutuhkan bantuan dari berbagai aspek, terutama bantuan-bantuan yang dapat mendukung peningkatan kinerjanya.

Berdasarkan hasil pengamatan dan interview dengan beberapa tenaga administrasi sekolah di SMPSekolah Menengah Pertama Negeri Kota Bamdung, peneliti menyimpulkan bahwa kurangnya semangat kerja dipengaruhi oleh beberapa faktor, antara lain :

1. Modal Sumber Daya Manusia, faktor ini terkait dengan kebiasaan dan perilaku sesorang, jika seseorang sudah terbiasa bekerja giat (cepat), maka dia akan terlihat lebih bersemangat daripada orang yang terbiasa bekerja lambat. Faktor ini juga terkadang dapat dipengaruhi oleh faktor usia dari tenaga administrasi sekolah tersebut, karena seperti yang telah dipaparkan dalam latar belakang penelitian, tenaga administrasi sekolah di Sekolah Menengah Pertama Negeri Kota Bandung berada pada usia tidak produktif yaitu $69 \%$ berada pada usia rentang 51-60 tahun.

2. Kepuasan materi dan non materi, faktor kepuasan yang didapat dari berusaha, kepuasan ini bisa bersifat materi ataupun non materi. Misalnya seseorang akan lebih bersemangat ketika ia mendapatkan uang yang lebih banyak dari pada biasanya. Hal ini terkait dengan kompensasi dan tunjuangan yang didapatkan oleh para tenaga administrasi sekolah, berdasarkan hasil interview dari beberapa sumber tenaga administrasi sekolah di Sekolah Menengah Pertama Negeri Kota Bandung, mereka mengeluhkan ketidakadilan pemeberian kompensasi dan tunjangan yang pemerintah berikan antara tenaga administrasi sekolah dan para guru.

3. Kesesuaian bakat dan minat, faktor kesesuai bakat dan minat ini artinya orang akan lebih bersemangat bekerja apabila pekerjaannya sesuai dengan bakat yang dimilikinya dan disenanginya. Berbeda jika tidak sesuai dengan bakat dan minat yang dimiliki, tentunya pekerjaan juga kurang baik. Hal tersebut terindikasi dari hasil studi pendahuluan yang dilakukan peneliti, ditemukan bahwa 51\% dari jumlah tenaga administrasi sekolah di Sekolah Menengah Pertama Negeri Kota Bandung hanya berpendidikan Sekolah Menengah Atas yang tak jarang tidak mahir dalam menggunakan alat teknologi informasi dan komunikasi.

Pemerintah tentunya sebagai lembaga tertinggi, harus selalu berusaha untuk meningkatkan semangat kerja semaksimal mungkin dalam batas-batas kemampuan yang wajar. Beberapa cara untuk meningkatkan semangat kerja baik yang berupa materil atau non material antara lain : gaji yang cukup, kebutuhan rohani, menciptakan suasan santai, penempatan 
posisi karyawan, pemberian insentif yang sesuai, dan fisilitas yang memadai.

Begitu pula teori yang dinyatakan oleh Tohardi (2002, hlm. 54) menyatakan bahwa ada lima alasan pentingnya semangat kerja bagi organisasi atau perusahaan yaitu: (1) dengan adanya semangat kerja yang tinggi dari karyawan maka pekerjaan yang diberikan akan dapat diselesaikan dengan waktu yang lebih singkat dan lebih cepat, (2) dengan semangat kerja yang tinggi tentunya dapat mengurangi angka absensi (bolos) atau tidak bekerja karena malas, (3) dengan semangat kerja yang tinggi pihak organisasi atau perusahaan memperoleh keuntungan dari sudut kecilnya angka kerusakan, (4) dengan semangat kerja yang tinggi otomatis membuat pekerja atau karyawan akan merasa betah (senang) bekerja, dan (5) dengan semangat kerja yang tinggi juga dapat mengurangi angka kecelakaan.

\section{Pembahasan Pemanfaatan Sarana Prasarana Kerja}

Sarana Prasarana Pendidikan, dalam hal ini sarana prasarana kerja administrasi sekolah sebagai salah satu penunjang keberhasilan pendidikan yang mengacu pada standar sarana dan prasarana yang ditetapkan dengan Peraturan Menteri, seringkali menjadi kendala dalam proses penyelenggaraan pendidikan di Sekolah. Kendala-kendala yang dihadapi antara lain adalah adanya penyediaan sarana yang belum memadai atau lengkap. Permasalahan sarana prasarana sangat penting untung ditangani lebih serius, karena sangat berpengaruh dalam kelancaran proses kerja tenaga administrasi sekolah, karena disamping menjadikan pekerjaan lebih ringan, tentunya semua sarana prasarana itu harus sesuai dengan kebutuhan dan perkembangan ilmu pengetahuan dan komunikasi. Seringkali dalam pemenuhan sarana prasarana ditentukan oleh pihak sekolah bersama komite sekolah berdasarkan pada keinginan dan kebutuhan sekolah masing-masing. Bagi beberapa Sekolah Menengah Pertama Negeri di Kota Bandung yang telah memenuhi sarana prasarananya akan meningkatkannya agar lebih baik lagi. Hal tersebut merupakan hal yang wajar sebagai upaya untuk meningkatkan kwalitas kerja tenaga administrasi sekolah.

Adapun permasalahan yang sering timbul adalah tidak terkendalinya rencana yang diprogramkan oleh pihak sekolah dengan harapan untuk memenuhi keinginan secara maksimal yang sering kali kurang efektif karena tidak langsung dapat digunakan untuk memenuhi kebutuhan kerja para tenaga administrasi sekolah yang bersangkutan, hal ini bisa terjadi karena tidak adanya standarisasi yang diharuskan untuk dipenuhinya. Bagaimanapun juga peningkatan kualitas tenaga administrasi sekolah memang bukan hal yang mudah, terutama jika alokasi anggaran pendidikan di suatu daerah belum memungkinkan untuk mencapai angka ideal. Oleh karena itulah, berbagai alternatif kebijakan bersifat efektif dan efisien, seperti peningkatan sarana prasarana secara partisipatif yang juga mengikut sertakan kearifan lokal daerah, peningkatan pengawasan terpadu stake holder pendidikan dan pemerintah daerah berkaitan dengan kebijakankebijakan pendidikan.

\section{Pembahasan Self Capacity Building}

Dalam elemen self capacity building, tenaga administrasi sekolah merupakan bagian yang berada pada level individual dan level organisasi. Hal ini karena berkaitan dengan pelaksanaan tenaga administrasi sekolah sebagai individu dan bagian dari sebuah sekolah dalam melaksanakan tugas dan kemampuan dalam kinerja administrasi sekolah. Penerapan self capacity building pada tingkat individu merupakan bagian yang di dalamnya terdapat peningkatan pengetahuan dengan cara mengikuti seminar, pelatihan, workshop dan kegiatan lainnya yang sejenis. Dalam tingkat individu juga penerapannya dapat berupa pengembangan pada kemampuan tenaga administrasi sekolah yang dapat meningkatkan kinerja.

Merujuk pada penelitian terdahulu oleh Matseliso (2008, hlm. 1112), adanya interaksi dan kolaborasi dalam program self capacity building secara berkelanjutan mempunyai dampak yang baik dalam bidang pendidikan. Kenyataan itu telah memberikan ilustrasi bagaimana beberapa sekolah, dan guru pada khususnya, telah berhasil membuat kesempatan untuk belajar menjadi lebih baik dan melanjutkan pendidikan di lingkungannya meskipun dengan keterbatasan kapasitas individu masing-masing.

\section{Pengaruh Pemanfaatan Sarana Prasarana Kerja terhadap Kinerja Tenaga Administrasi Sekolah}

Dari hasil penelitian yang telah dilakukan menunjukkan bahwa Pemanfaatan Sarana Prasarana Kerja berpengaruh dan signifikan terhadap Kinerja Tenaga Administrasi Sekolah. Berkaitan dengan hal tersebut, hasil penelitian yang dilakukan oleh Rev. John Karihe, Prof. Namusonge, dan DR. Mike Iravo (2015, hlm. 525) menyebutkan bahwa ada pengaruh yang signifikan secara statistik dari fasilitas kerja terhadap kinerja karyawan. Penelitian tersebut merekomendasikan 
para pemangku kebijakan publik untuk lebih memperhatikan peningkatan penyediaan fasilitas kerja yang diperlukan untuk karyawan. Berdasarkan hasil penelitian, fasilitas tempat kerja adalah kontributor utama stres kerja dan akibatnya mempengaruhi kinerja karyawan. Oleh karena itu peningkatan penyediaan fasilitas yang diperlukan di tempat kerja karena akan berdampak terhadap peningkatan kinerja para karyawan. Penelitian tersebut juga menjelaskan stres karyawan dapat dipicu dari kurangnya penyediaan fasilitas tempat kerja dan sumber daya seperti beban kerja yang wajar, kantor yang memadai ruang, peralatan dan bahan untuk melakukan tugas-tugas sesuai prosedur perusahaan, dan cukup waktu untuk melakukan tugas.

Penelitian lainnya yang dikemukakan oleh Didi Hartono (2014, hlm. 142) menunjukkan bahwa sarana prasarana berpengaruh signifikan terhadap kinerja pegawai karena sarana prasarana dan lingkungan kerja mempunyai pengaruh yang besar terhadap kinerja pegawai. Oleh karena itu pentingnya sarana prasarana kerja yang baik dan dapat digunakan dalam melaksanakan pekerjaan sedangkan lingkungan kerja harus selalu diperhatikan agar tetap terjaga keyamanannya, lingkungan lingkungan kerja yang baik tentunya akan dapat menciptakan suasana yang nyaman bagi pegawai untuk bekerja dan beraktivitas sehingga akan dapat meningkatkan kinerja organisasi secara keseluruhan. Sarana prasarana berpengaruh terhadap kinerja pegawai, sehingga pentingnnya penyediaan sarana prasarana yang sesuai dengan standar kerja dan dapat berfungsi dalam pelaksanaan tugas dan pekerjaan pegawai baik berupa gedung perkantoran maupun alat pekerjaan seperti komputer, alat tulis, jaringan internet dal lain-lainnya.

Penelitian-penelitian diatas menunjukkan bahwa sarana prasarana kerja bukan sekedar unsur penunjang bahkan bisa menjadikan kunci kesuksesan dari sebuah optimalisasi suatu pekerjaan yang tentu akan berdampak pada keberhasilan pencapaian tujuan sebuah organisasi.

\section{Pengaruh Self Capacity Building terhadap Kinerja Tenaga Administrasi Sekolah}

Dari hasil penelitian yang telah dilakukan, self capacity building cukup berperan penting bagi peningkatan kinerja tenaga administrasi sekolah. Dengan adanya self capacity building yang dilakukan oleh para tenaga administrasi sekolah maka secara tidak langsung kemampuan mereka dalam melakukan suatau pekerjaan dapat bertambah yang tentunya sesuai dengan perkembangan dunia kerja ilmu keadministrasian yang semakin kompleks. Hal ini sependapat dengan Kaniaru (2002, hlm. 56) menegaskan bahwa definisi dari pengembangan kapasitas itu sendiri merupakan pembangunan kemampuan, hubungan antar pekerja, dan nilai yang dapat memudahkan organisasi atau individu dalam meningkatkan kemampuan mereka dan mampu mengembangkan cara untuk mencapai tujuan. Hal tersebut dapat dilakukan dengan mengikuti pelatihan dan berbagai kegiatan yang dapat mengembangkan potensi dan mempererat jalinan antara para pekerja.

Penelitian lainnya dilakukan oleh GreenLee (2010, hlm. 401) penelitian ini menunjukan bahwa keikutsertaan guru dalam pengembangan self capacity building pada ranah kepemimpinan baik yang diikuti oleh guru maupun kepala sekolah mempunyai pengaruh dalam perubahan pembelajaran di sekolah yang menjadi lebih efektif. Penelitian ini berfokus pada bagaimana gambaran penguasaan kompetensi guru dalam belajar bahasa di sekolahnya. Hasil penenlitian menunjukan bahwa kompetensi guru dalam penguasaan materi, metode, dan penyiapan bahan belajar berpengaruh pada pengembangan dan pembiasaan belajar yang baik bagi guru itu sendiri, dan seharusnya dibutuhkan program pengembangan bagi para guru untuk meningkatkan kinerja mengajarnya.

Penelitian-penelitian diatas menunjukkan bahwa self capacity building bisa menjadi suatu alternatif dalam meningkatkan kinerja seseorang yang tentu akan berdampak pada keberhasilan pencapaian tujuan sebuah organisasi. Seperti yang dijelaskan oleh Brown dan Rainer Rohdewohld (2005, hlm. 11) yang mendefinisikan "Capacity building is a process that increases the ability of persons, organisations or system to meet its stated purposes and objectives". Dari pengertian tersebut dapat dimaknai bahwa Pengembangan Kapasitas adalah suatu proses yang dapat meningkatkan kemampuan seseorang, organisasi atau sistem untuk mencapai tujuan yang hendak dicapai.

Hal tersebut sejalan dengan Morgan (2006, hlm. 58), yang mengemukakan pengembangan kapasitas adalah proses yang dialami oleh individu, kelompok dan organisasi untuk memperbaiki kemampuan mereka dalam melaksanakan fungsi mereka dan mencapai hasil yang diinginkan. Dari pengertian tersebut dapat memberi penekanan pada dua hal penting: 1) pengembangan kapasitas sebagian besar berupa proses pertumbuhan dan pengembangan internal, dan 2) upaya-upaya pengembangan kapasitas haruslah berorientasi pada hasil. Tujuan utama pengembangan kapasitas 
diri itu sendiri merupakan upaya untuk meningkatkan kemampuan sesorang agar dapat melaksanakan fungsi-fungsi essensial, baik dalam memecahkan masalah, menetapkan dan mencapai tujuan, dan mengerti serta bisa menangani kebutuhan pengembangan diri mereka dalam suatu lingkungan yang lebih luas secara berkelanjutan.

\section{Pengaruh Pemanfaatan Sarana Prasarana Kerja dan Self Capacity Building terhadap Kinerja Tenaga Administrasi Sekolah}

Dari hasil penelitian ini menunjukkan bahwa terdapat pengaruh dan signifikan antara Pemanfaatan Sarana Prasarana Kerja dan Self Capacity Building terhadap Kinerja Tenaga Administrasi Sekolah di Sekolah Menengah Pertama Negeri Se Kota Bandung. Kinerja Tenaga Administrasi Sekolah dipengaruhi oleh variabel Pemanfaatan Sarana Prasarana Kerja dan Self Capacity Building sebesar $69,5 \%$ sedangkan selebihnya $30,5 \%$ dipengaruhi oleh faktor lain. Misalnya faktor kepemimpinan, faktor kualitas kerja, faktor motivasi, dan lain-lain.

Sebagai sebuah sistem, sekolah terdiri dari beberapa komponen yang saling berhubungan dan saling mempengaruhi antara yang satu dengan yang lainnya. Satu di antara komponen tersebut adalah tenaga administrasi sekolah di jenjang sekolah dasar dan menengah. Tenaga administrasi sekolah memiliki peran penting dalam mewujudkan tujuan organisasi pendidikan yang pada gilirannya memberikan pengaruh yang signifikan terhadap pencapaian tujuan pendidikan nasional. Peran tenaga kependidikan memang tidak terlibat secara langsung dalam kegiatan belajar mengajar, akan tetapi peranannya cukup penting dalam mendukung kelancaran kegiatan belajar dan pelayanan pendidikan.

Tenaga administrasi merupakan salah satu jenis tenaga kependidikan yakni adalah tenaga di luar tenaga pengajar yang tugasnya mempersiapkan dan memperlancar pelaksanaan pendidikan baik secara teknis maupun manajerial. Keberadaan tenaga administrasi sekolah akan sangat mendukung peningkatan mutu dan pelayanan pendidikan. Kompetensi tenaga administrasi sekolah sangat diperlukan bagi kelangsungan mutu sekolah dalam dunia pendidikan. Hal ini sesuai dengan pemenuhan standar kualifikasi dan kompetensi standar yang ditetapkan dalam Peraturan Menteri Pendidikan Nasional Republik Indonesia Nomor 24 Tahun 2008 tentang Standar Tenaga Administrasi Sekolah.

Dari pernyataan tersebut dapat dikatakan untuk meningkatkan kinerja tenaga kependidikan dapat dilakukan dengan beberapa cara. Walaupun hubungan antara mutu pendidikan sebuah sekolah dengan kinerja tenaga administrasi sekolah merupakan hubungan yang bersifat tidak langsung, namun harus diakui bahwa kinerja pegawai tata usaha sekolah turut mempengaruhi mutu pendidikan sebuah sekolah. Karenanya, upaya peningkatan mutu pendidikan juga harus menyentuh peningkatan kinerja tenaga administrasi sekolah agar mereka bisa memberikan kontribusi yang lebih besar bagi peningkatan mutu pendidikan di sebuah sekolah.

Pengaruh Pemanfaatan Sarana Prasarana Kerja dan Self Capacity Building terhadap Kinerja Tenaga Administrasi Sekolah di SMP Negeri Kota Bandung tidak terlepas dari konsep teori kinerja yang dipengaruhi beberapa faktor. Seperti yang dijelaskan oleh Sutermeister (1976, hlm. 11), Kinerja atau performance dipengaruhi oleh 2 unsur yaitu motivation dan ability. Unsur-unsur yang ada dari motivasi yaitu phsycal conditions, individuals phsycological social egoistic, formal organization, informal organization (groups). Unsur dari ability yaitu skill dan knowledge.

Faktor pertama yang mempengaruhi kinerja dari unsur motivation (motivasi) yaitu dilihat dari phsycal conditions atau kondisi fisik, yaitu yang termasuk didalamnya adalah saran pra sarana kerja.

Faktor kedua yang mempengaruhi kinerja dari unsur ability (kemampuan) adalah Self Capacity Building. Pada prosesnya, capacity building merupakan sebuah pengembangan yang akan menuntut kegiatan sebuah organisasi mencapai tujuannya, hal tersebut seperti yang dijelaskan Matachi (2006, hlm. 4) yang mengatakan bahwa : "Capacity building is a process by wich individuals, groups, institutions, organizations and societies enhance their abilities to identify and meet development challenges in a sustainable manner". Maksud dari pernyataan tersebut merupakan pengertian dari pengembangan kapasitas yang dapat diartikan sebagai proses untuk meningkatkan kemampuan individu, organisasi, dan sebuah institusi untuk meningkatkan kemampuan dalam menghadapi tantangan yang berkelanjutan.

Dalam self capacity builing secara tidak langsung mempersiapkan interaksi antar individu, hal tersebut seperti dipaparkan oleh Matachi (2006, hlm. 4) yang mengemukakan bahwa : Any self capacity building activity, including training workshop and country projects, should make an effort to build capacity of stakeholders from 
different groups of socienty, and provide a platfrom for these groups to interact with each other.

Untuk itu kemajuan suatu sekolah sebagai lembaga pendidikan tergantung dari kemampuan personil administrasinya. Kemajuan sekolah tersebut yang tidak kalah pentingnya adalah meningkatkan kinerja tenaga administrasi sekolah yang profesional adalah tenaga administrasi sekolah yang memiliki kemampuan dan ketarmpilan secara profesional yang didaptkan secara terus menerus dalam melaksanakan tugas pokok dan fungsinya. Guna meningkatkan kinerja tenaga administrasi sekolah maka tenaga administrasi sekolah perlu melaksanakan serangkaian upaya yang mengarahkan tenaga administrasi sekolah pada peningkatan kemampuan, kecakapan atau keterampilan untuk melaksanakan administrasi sekolah.

Seiring perubahan sistem administrasi sekolah yang sering berubah baik dari segi software atau aplikasi maupun petunjuk teknisnya, maka tenaga administrasi sekolah dituntut untuk dapat meng-upgrade dan menyesuaikan perubahan tersebut, hal ini dimaksudkan agar dapat menyesuaikan perubahan tersebut. Oleh sebab itu, tenaga administrasi sekolah perlu melakukan upaya-upaya guna meningkatkan pengetahuan dan keterampilannya dalam hal administrasi sekolah. Dengan self capacity building yang dilakukan oleh para tenaga administrasi sekolah guna meningkatkan profesionalitas tenaga administrasi sekolah.

\section{SIMPULAN DAN REKOMENDASI}

Kinerja Tenaga Administrasi Sekolah di Sekolah Menengah Pertama Negeri Se Kota Bandung secara keseluruhan berada pada kategori sangat tinggi Hal ini dapat diketahui dari dimensidimensi variabel ini, yaitu: Pertama, loyalitas mencapai skor rata-rata yang sangat tinggi. Kedua, semagat kerja mencapai skor rata-rata yang tinggi. Ketiga, prakarsa yang mencapai skor rata-rata yang tinggi. Keempat, tanggung jawab yang mencapai skor rata-rata yang sangat tinggi. Kelima, pencapaian target yang mencapai skor rata-rata yang tinggi. Pemanfaatan Sarana Prasarana Kerja di Sekolah Menengah Pertama Negeri Se Kota Bandung secara keseluruhan berada pada kategori sanggat tinggi. Hal ini dapat diketahui dari indikator variabel ini, yaitu: Pertama, efisiensi mencapai skor rata-rata yang sangat tinggi. Kedua, efektivitas mencapai skor rata-rata yang sangat tinggi. Ketiga, administratif mencapai skor ratarata yang sangat tinggi. Keempat, Peralatan atau perlengkapan kantor (office supplies) mencapai skor rata-rata yang sangat tinggi. Kelima, mesinmesin kantor (office machine) mencapai skor ratarata yang tinggi. Keenam, mesin komunikasi kantor (office communication machine) mencapai skor rata-rata yang sangat tinggi. Ketujuh, Perabot kantor (office furniture) mencapai skor rata-rata yang sangat tinggi. Kedelapan, Interior kantor (office arrangement) mencapai skor rata-rata yang tinggi. Kesembilan, Tata ruang kantor (office lay out) mencapai skor rata-rata yang sangat tinggi. Hal ini menunjukan bahwa Sarana Prasarana Kerja di Sekolah Menengah Pertama Negeri Se Kota Bandung telah memberikan kontribusi yang baik sebagai fasilitas penunjang dalam proses kerja. Self Capacity Building yang dilakukan oleh para tenaga administrasi sekolah di Sekolah Menengah Pertama Negeri Se Kota Bandung secara keseluruhan berada pada kategori tinggi. Hal ini dapat diketahui dari indikator-indikator variabel ini, yaitu: Pertama, workshop mencapai skor ratarata yang tinggi. Kedua, seminar mencapai skor rata-rata yang tinggi. Ketiga, course (kursus) mencapai skor rata-rata yang tinggi. Keempat, Cooperative collegial development mencapai skor rata-rata yang tinggi. Kelima, Skill development model mencapai skor rata-rata yang tinggi. Hal ini menunjukan bahwa self capacity building yang dilakukan oleh para tenaga administrasi sekolah di Sekolah Menengah Pertama Negeri Kota Bandung sudah cukup baik, dengan demikian kemampuan dan pengetahuan para tenaga administrasi sekolah dapat terus bertambah sesuai dengan perkembangan ilmu pengetahuan dan teknologi. Sarana Prasarana Kerja memberikan manfaat yang signifikan terhadap Kinerja Tenaga Administrasi. Hal ini memiliki makna bahwa semakin baik Sarana Prasarana Kerja yang tersedia maka Kinerja Tenaga Administrasi Sekolah akan semakin efektif. 
Afriyenti (2013). Pemberdayaan Pegawai Tata Usaha Dalam Rangka Meningkatkan Layanan Administratif. Jurnal Bahana Manajemen Pendidikan, Vo 1 (1), 9 -13.

Arikunto S, (2006). Prosedur Penelitian Suatu Pendekatan Praktik, Ed Revisi VI. Jakarta: PT Rineka Cipta

Arum, Wahyu Sri Ambar. (2007). Manajemen Sarana dan Prasarana. Jakarta:CV. Multi Karya Multi

Brown, Rainer Rohdewohld (2005). Measuring Capacity Building. Carolina Population Centre/University of North Carolina: Chapel Hill

Greenlee B.J. (2010). Building Teacher Leadership Capacity through Educational Leadership Program. Journal of Reasearch for Educational Leaders JREL, 4 ( 1), hlm. 44 - 74

Hartono, Didi. 2014. Pengaruh Sarana Prasarana Dan Lingkungan Kerja Terhadap Kinerja Pegawai Dinas Pendidikan Kota Banjarbaru, Kindai. 10 (2), 142-155.

Hazel Callaghan. (2011). Raising Standards Improving Lives : The Office for Standards in Education: Journal Ofsted Raising Standards Improving Lives, 3(2), hlm 10-12.

James P. Spillane \& Allison W. Kenney. (2012). School administration in a changing education sector the US experience: Journal of Educational Administration, 50(5), hlm. 541-561.

Kaniaru, D, Kunbao Xia, dkk. (2002). Capacity Building for Sustainable Development. UNEP Division of Comunications and Public Informantion.

Matachi. (2006). Capacity Building Framework UNESCO-IICBA. Addis Ababa: United Nations Economic Commission for Africa
Matseliso, L.M \& Loyiso C.J. (2008). Self Capacity Building for Teaching and Learning in Environmental Education The Role of Public/Private Partnerships in the Mpumalanga Privince of South Africa. Journal International Cooperation in Education, 1 ( 3), hlm.. $39-54$

Morgan, Peter. (2008). The Concept Of Capacity. England: European Centre For Development Policy Management.

Peraturan Menteri Pendidikan Nasional Republik Indonesia Nomor 24 Tahun 2008 tentang Standar Tenaga Administrasi Sekolah

Rev. John Karihe, Prof. Namusonge, DR. Mike Iravo. (2015). Work Facilities as a Determinant of Occupational Stress and Employee Performance. International Journal of Science and Research, 4(5), hlm. $1925-1930$

Sartini. 2010. Kinerja Tata Usaha Sekolah Menengah Kejuaruan (SMK) PGRI Se DKI Jakarta, Jurnal Sosio E-Kons, 2 (3), $24-54$.

Sudjana. (2009). Metode Statistika, Bandung: Tarsito

Sugiyono. (2009). Statistika Untuk Penelitian. Bandung: Cv Alfabeta

Sutermeister. (1976). People and Productivity. Amerika: Library of Congress Cataloging in Publication Data

Tartini dan Zulkifli. (2016). Kompetensi Manajerial Kepala Tenaga Administrasi SMA/MA/SMK Di Kabupaten Belitung. EKSIS, 11 (2), 151 - 164.

Tohardi Ahmad, (2002), Pemahaman Praktis Manajemen Sumber Daya Manusia, Universitas Tanjung Pura, Mandar Maju, Bandung.

Wibowo. (2007). Manajemen Kinerja. Jakarta: PT Rajagrafinda Persada. 